\title{
Universiteit
}

Leiden

The Netherlands

\section{Cultuur, acculturatie en afwijkende ontwikkeling}

Vedder, P.H.

\section{Citation}

Vedder, P. H. (2008). Cultuur, acculturatie en afwijkende ontwikkeling. In Handboek Klinische Ontwikkelingspsychologie. Over aanleg, omgeving en verandering (pp. 209-229). Bohn Stafleu van Loghum. Retrieved from https://hdl.handle.net/1887/16576

\footnotetext{
Version: $\quad$ Not Applicable (or Unknown)

License: $\quad$ Leiden University Non-exclusive license

Downloaded from: https://hdl.handle.net/1887/16576
}

Note: To cite this publication please use the final published version (if applicable). 
8 Cultuur, acculturatie en afwijkende ontwikkeling

Paul Vedder

De in dit hoofdstuk samengebrachte onderwerpen immigratie en afwijkende ontwikkeling creëren in hun combinatie een gevoelig thema. In politieknationalistische kringen, zowel tegenwoordig als in het verleden, worden immigranten beschouwd als 'vreemdelingen' en als 'brengers van het

kwaad', als 'ontwrichters van rust en waardigheid' of in een moderne variant 'bedreigers van sociale cohesie' (Lucassen, 2006). Een tekst over immigranten en afwijkend gedrag zou allicht olie op het vuur kunnen zijn voor nationalistische politici en angstige en vreemdelingenhatende burgers. Dat is niet de bedoeling. Doel van deze tekst is na te gaan of er reden is om in het kader van de geestelijke gezondheidszorg speciale aandacht te schenken aan immigranten en hoe dat dan het beste kan. Daarbij wordt ingegaan op vragen als: hoe wordt bepaald of een afwijkende persoonlijke ontwikkeling samenhangt met immigratie; wat zijn verklaringen voor een dergelijke ontwikkeling en wat zijn de mogelijkheden van preventie of behandeling?

In de titel van dit hoofdstuk wordt gerept over cultuur en acculturatie, maar niet over immigratie en immigranten. Dit hangt samen met de eerste hierboven gestelde vraag: hoe wordt bepaald of een afwijkende persoonlijke ontwikkeling samenhangt met immigratie? Immigranten zijn personen die zich voor langere tijd komen vestigen in een ander land. De meeste van hen zijn opgegroeid in en met een cultuur die in meerdere of mindere mate verschilt van die van het nieuwe land waar ze zich gaan vestigen. Met de term cultuur verwijzen we naar een levensstijl en leefomgeving die kenmerkend is voor een groep personen. Daarbij gaat het om tussen personen over te dragen waarden en waardepatronen (bijv. godsdienst, juridische systemen), om gedachten en via symbolen of woorden weergegeven betekenissystemen, maar ook om de inrichting van een samenleving (gezinsstructuur, de arbeidsmarkt) en technologische ontwikkelingen (voedselproductie, gezondheidsindustrie) (Müller, 2006).

Cultuur wordt van mens tot mens doorgegeven, het meest nadrukkelijk in opvoeding en onderwijs. Dat maakt dat cultuur de ontwikkeling van mensen 
bepaalt, inclusief de afwijkende ontwikkeling, en mede daardoor is er sprake van verschillen tussen personen met een verschillende culturele achtergrond; bijvoorbeeld tussen verschillende groepen migranten en de groep waarmee ze gaan samenleven, de autochtonen. Deze verschillen noemen we hier oorspronkelijke verschillen; verschillen die bestaan zonder dat culturele groepen direct contact hebben met elkaar. Oorspronkelijke verschillen worden onderzocht in internationaal vergelijkend onderzoek naar groeps- of cultuurgebonden verschillen in de mate waarin bepaalde patronen van afwijkende ontwikkeling (prevalentieverschillen) voorkomen. Van deze oorspronkelijke groepsverschillen moeten we kennis hebben om de kern te achterhalen van waar het in dit hoofdstuk om gaat, namelijk een afwijkende ontwikkeling die samenhangt met de ervaring van het verlies van contact met een eerdere gemeenschap en van het nieuwe contact met één of meerdere andere culturele gemeenschappen. Dit wordt acculturatie genoemd (zie box 8.1).

Niet alle uitingen van afwijkende ontwikkeling bij immigranten hangen samen met acculturatieprocessen; sommige gaan terug op cultuurgebonden of genetische verschillen die voorafgaand aan emigratie aanwijsbaar zijn. Over genetische verschillen wordt in box 8.2 meer geschreven.

\section{Voorbeeld cultuurgebonden verschillen}

Vedder (7995) liet zien dat de waardering voor agressief gedrag (veel vechten en de baas spelen) bij Antilliaanse jongens die op de Antillen woonden overwegend positief was. Bii hun Nederlandse leeftijdgenoten in Nederland was de waardering juist negatief, terwijl Antilliaanse leeftijdgenoten die immigrant waren in Nederland een mooie tussenpositie innamen. Deze onderzoeksbevindingen wijzen erop dat de aanvankelijk positieve houding tegenover agressief gedrag bij Antilliaanse jongens die naar Nederland komen, verandert in de richting van een negatieve houding die meer typisch is voor Nederlandse leeftijdgenoten. De aanvankelijke positieve houding is een oorspronkelijk verschil dat vedder via een verwijzing naar opvoedingspraktijken en leefomstandigheden en vanwege de veranderlijkheid benoemt als een cultuurverschil.

\section{Box 8.1 Acculturatie, cultuurbehoud en cultuunverlies}

De meest aangehaałde definitie van acculturatie is geformuleerd in 1936 door Redfield, Linton en Herskovits, voorzitter en leden van de Onderzoeksraad voor de sociale wetenschappen van de Verenigde Staten. Zij omschreven acculturatie als die verschijnselen die optreden door direct contact tussen groepen individuen die afkomstig zijn uit verschillende culturen en die aanleiding zijn tot verandering in de oorspronkelijke culturele patronen van een of meerdere groepen. Een invloedrijke uitwerking van deze definitie is van de Canadese cultuurvergelijkende psycholoog Berry.

In Berfy's model (o.a. Berry, 1980) gaat het orn twee vragen waarmee wordt nagegaan hoe de interculturele leefsituatie van immigranten eruitziet. De eerste heeft betrekking op cultuurbehoud: wordt het belangrijk geacht on de eigen cultuur vast te houden? De tweede heeft betrekking op de relaties met de cultuur van de nieuwe samenleving: wordt het belangrijk geacht om banden aan te gaan en te onderhouden met de nieuwe samenleving? Indien voor het gemak verondersteld wordt, dat beide vragen enkel met 'ja' en 'nee' beantwoord kunnen worden, geven deze informatie over vier mogelijke acculturatiestijlen. Deze worden aangeduid als integratie, assimilatie, separatie en marginalisatie: Twee positieve antwoorden wijzen op integratie, terwijl twee negatieve antwoorden duiden op marginalisatie. Een positief antwoord op de eerste vraag en een negatief antwoord op de tweede leidt tot separatie, en een combinatie van nee op behoud en ja op aanpassing duidt op assimilatie. Berry onderstreept met zïn model dat migranten niet hun eigen cultuur hoeven op te geven om zich in hun nieuwe leefsituatie te kunnen richten op de nieuwe culturele omgeving. Berry en andere onderzoekers (zie o.a. Berry, Phinney, Sam \& Vedder, 2006) hebben herhaaldelijk betoogd dat een keuze voor integratie samengaat met minder stress en meer welbevinden bij migranten dan de andere acculturatiestijlen. Berr's model benadrukt vooral het perspectief van de immigranten.

Cultuurbehoud speett een rol in het leven van veel immigranten. On de betekenis ervan te doorgronden is het verhelderend on cultuurbehoud te bezien vanuit de zorg om cultuunverties. Een voorbeeld: Antilliaanse kinderen die gedurende de schoolleeftijd naar Nederland komen ontwikkelen koit na hun eerste ervaring met Nederlandse scholen hoge niveaus van faalängst. Opeens is veel van wat ze op school op de Antillen hebben geleerd niet meer functioneel. Opeens zitten ze in een context waarin ze zich individueel moeten onderscheiden en verantwoorden. Immigratie betekent voor deze kinderen niet slechts het opgeven van sociale contacten op de Antillen, maar ook een proces van herwaardering van kennis, vaardigheden en waarden dat gepaard gaat met processen van cultuurverlies op individueet niveau. In de relatie tussen individu en greep kan culturverlies een verlies van sociale contacten of destabilisering van contacten inthouden. Destabilisering van contacten kan optreden doordat bijvoorbeeld niet iedereen in de gemeen:schap nog dezelfde taal spreekt, of doordat de binding niet mee wordt versterkt via religieuze bijeenkomsten. Cultuurverlies is voor veel migranten een pijnlijk proces.

2.

\subsection{Prevalentie van probleemgedrag}

Net als elders in Europa is er in Nederland en Vlaanderen weinig bevolkingsonderzoek gedaan om de prevalentie van afwijkende ontwikkeling vast 
te stellen. Voor zover er onderzoek is gedaan, is weinig of geen aandacht geschonken aan leden van een andere dan de nationale cultuur. Mogelijke redenen zijn:

- de andere etnische groepen zijn relatief klein en dit uit zich in een te klein aantal deelnemers aan het onderzoek

- er is een hoge weigering of er is sprake van het ontwijken van deelname (niet thuis zijn op de beoogde tijd)

- de onderzoeksinstrumenten zijn niet goed aangepast aan gebruik in verschillende etnische groepen (er wordt geen rekening gehouden met ongeletterdheid en de vragenlijsten zijn niet vertaald en gevalideerd voor verschillende etnische groepen).

Wat is er niet bekend? Het antwoord op deze vraag is te vinden in een notitie van het Trimbos-instituut, het Nederlandse kennisinstituut voor geestelijke gezondheidszorg. De notitie is opgesteld ten behoeve van het voorbereiden van onderzoek met meer aandacht voor culturele of etnische minderheden in Nederland (De Graaf, Ten Have, Van Dorsselaer, Schoemaker \& Vollebergh, 2004). Het antwoord was duidelijk en kort, er zijn geen representatieve gegevens over het voorkomen van depressies, angststoornissen, antisociale persoonlijkheidsstoornissen (verslaving, criminaliteit), aandachtsproblemen (ADHD) en autismespectrumstoornissen onder immigranten in Nederland. Hiernaar is geen of onvoldoende onderzoek gedaan. Ook is aan de voorlichtingsafdeling van Mikado, het kenniscentrum voor interculturele geestelijke gezondheidszorg in Nederland, gevraagd naar de proportie migrantenjongeren met psychische of psychiatrische problemen. Wederom was het antwoord kort en bondig, goede, betrouwbare cijfers zijn niet beschikbaar (email Mikado, 4 september 2006). Deels is het feit dat tussen de zorginstellingen geen eensgezindheid bestaat over de wenselijkheid van het registreren van de etnische achtergrond van cliënten hier debet aan; van 42 procent is de etnische achtergrond niet bekend. Bovendien levert het registreren van bezoek aan zorginstellingen geen representatief beeld op. Volgens Mikado blijkt uit onderzoek en ervaring dat de jeugdzorg slecht toegankelijk is voor migrantenjeugd. Jongeren uit de Nederlandse Antillen en Aruba zijn oververtegenwoordigd, evenals jongeren uit Afghanistan, terwijl Turkse en Marokkaanse jongeren ondervertegenwoordigd zijn (e-mail Mikado, 4 september 2006). In België lijkt de situatie iets gunstiger. Hier wordt sinds 1997 periodiek een nationale gezondheidsenquête verricht (Levecque, Lodewyckx \& Van den Eeden, 2006)

Onderzoek naar afwijkende ontwikkeling bij volwassenen

In 1996 heeft in Nederland de dataverzameling plaatsgevonden voor 'Netherlands Mental Health Survey and Incidence Study' (Nemesis), een bevolkingsonderzoek onder achttien- tot 65 -jarigen. De culturele of etnische achtergrond van de deelnemers werd bepaald aan de hand van het geboorteland van de respondent zelf of van diens ouders. Indien een deelnemer zel of een van diens ouders in Turkije was geboren werd de deelnemer tot de
Turkse groep gerekend. Er deden 6149 Nederlanders mee, 92 Surinamers, 36 Antillianen, 45 Turken en 26 Marokkanen (De Graaf, Ten Have, Van Dorsselaer, Schoemaker, Beekman \& Vollebergh, 2005). Ondanks dat het aantal deelnemende immigranten per groep klein was en de representativiteit werd betwijfeld, is vanwege gebrek aan betere gegevens toch gerapporteerd over deze groepen. Bij Surinamers en Marokkanen bleek sprake van een ver-

hoogde kans en bij Turken van een verlaagde kans op psychische problemen ten opzichte van de Nederlanders. Verder bleek in dit onderzoek dat de sociaaleconomische achtergrond, die bij de Turkse en Marokkaanse deelnemers gemiddeld lager was dan in de andere groepen, enige invloed had op de bevindingen; bij minder gunstige sociaaleconomische omstandigheden traden doorgaans meer problemen op.

Selten en collega's $(1997,2001)$ deden onderzoek op basis van registratiegegevens van volwassenen bij instellingen voor geestelijke gezondheidszorg. Dit berreft een selecte groep personen die de weg naar een instelling heeft gevonden. Selten en collega's stelden vast dat, in vergelijking tot autochtone Nederlanders, er bij Antilliaanse en Surinaamse immigranten sprake was van een verhoogde kans op schizofrenie. Bij Turkse migranten (tien personen) bestond geen verhoogd risico. Een verhoogd risico op psychosen was aanwezig bij eerstegeneratie Marokkanen (22 personen; een viermaal verhoogde kans), Surinamers (twintig personen; een tweemaal verhoogde kans), Antillianen (zes personen; een driemaal verhoogde kans) en andere nietwesterse immigranten (22 personen; een tweemaal verhoogde kans). Wat betreft tweedegeneratie-immigranten (in Nederland geboren kinderen van ouders die in het buitenland zijn geboren) was sprake van een verhoogd risico op psychosen bij Marokkanen (zes personen; een negenmaal verhoogde kans) en Sutinamers (elf personen; een vijfmaal verhoogde kans). De onderzoekers geven zelf aan dat de validiteit van de studie negatief wordt beïnvloed door het geringe aantal geregistreerde personen per etnische groep. Vooral de vergelijking tussen eerste- en tweedegeneratie-immigranten is hierdoor weinig krachtig, evenals de conclusies rond de Turkse en Antilliaanse immigranten.

Hiervoor werd al opgemerkt dat er in België een periodiek gezondheidsonderzoek wordt uitgevoerd. Tot dusver is dat gebeurd in 1997, 2001 en 2004. Om het onderscheid naar bevolkingsgroep te kunnen maken werd gekeken naar het geboorteland en de nationaliteit van de zogenaamde referentiepersoon; de persoon die uit het bevolkingsregister werd getrokken. Binnen de wooneenheid van de referentiepersoon konden nog maximaal drie familieleden van vijftien jaar en ouder meedoen aan het onderzoek. Zij werden tot dezelfde bevolkingsgroep gerekend als de referentiepersoon. Het gecombineerde gebruik van geboorteland en nationaliteit maakt het onmogelijk een onderscheid te maken naar generatie (eerste- of tweedegeneratie-immigrant). Elke tweedegeneratiemigrant die de Belgische nationaliteit heeft doet niet langer als migrant mee aan het onderzoek, maar als Belg. Verder is ervoor gekozen om vijf brede groepen te onderscheiden:

1 Belgen

2 de GIS-groep (Grieken, Italianen en Spanjaarden) 
3 overigen Europeanen zonder GIS

4 Turken en Marokkanen

5 anderen.

Het werken met deze brede groepen betekent onder meer dat er geen informatie beschikbaar is voor de Turkse en Marokkaanse groep afzonderlijk. Levecque en collega's (2006) hebben data van alledrie de metingen tot dusver of van de laatste twee metingen bij elkaar gevoegd, om zo de omvang van afzonderlijke groepen voldoende groot te maken. Ze richten zich op de groep vanaf vijftien jaar. Aan de metingen in 1997, 2001 en 2004 deden in totaal in Vlaanderen 10.008 Belgen mee, 70 GIS, 116 EU, niet-GIS, 300 Turken en Marokkanen en 198 anderen. Er was sprake van zelfrapportagevragenlijsten die deels schriftelijk konden worden ingevuld, deels via een interview. Voor het meten van de mentale gezondheid werd gebruikgemaakt van een verkorte versie van de 'general health questionnaire' en van de 'symptom checklist'. De onderzoekers stelden vast dat in de groep Turken en Marokkanen sprake was van een verhoogde kans op depressieve klachten en angststoornissen. De onderzoekers controleerden niet voor achtergrondverschillen tussen groepen. Dat deden Levecque, Lodewyckx en Vranken (2007) wel, maar dan zonder onderscheid te maken naar het Vlaamse en Waalse deel van België. $\mathrm{Zij}$ stelden vast dat ook als wordt gecontroleerd voor belangrijke verschillen tussen groepen wat betreft geslacht, leeftijd, type huishouden,

werksituatie en opleidingsniveau, er sprake blijft van een verhoogde kans op depressieve klachten in de groep Turken en Marokkanen.

Onderzoek naar afwijkende ontwikkeling bij jongeren

Er zijn verschillende studies uitgevoerd naar de geestelijke gezondheid van kinderen en jongeren, waarbij ook speciale aandacht is geschonken aan kinderen en jongeren uit immigrantengroepen. In 2001 zijn de eerste data verzameld van de 'tracking adolescent's individual lives survey' (Trials). Dit is een longitudinale studie naar de ontwikkeling van jongeren in Nederland (Vollebergh e.a., 2005). De eerste data zijn verzameld bij een representatieve steekproef van elfjarigen. Zij vulden zelf een vragenlijst in (de 'youth self report'), één van hun ouders vulde een andere lijst (de 'child behavior checklist') in en ook hun leerkracht vulde een vragenlijst in (de 'teacher's checklist of psychopathology'; een aangepaste en sterk verkorte versie van 'Achenbachs teacher's report form). Aan de studie namen 1928 Nederlandse, twaalf Turkse, vijftien Marokkaanse, 46 Surinaamse, 37 Antilliaanse en 38 Indonesische kinderen deel. Meisjes gaven aan over het algemeen iets meer internaliserende problemen (psychosomatische klachten en angstig depressief) te hebben, terwijl jongens iets meer externaliserende problemen agressiviteit en delinquentie) rapporteerden. De sociaaleconomische status bleek van invloed; een lagere SES ging gepaard met iets meer problemen. In hun verdere analyses hebben de onderzoekers rekening gehouden met deze verschillen. Immigrantenkinderen zelf rapporteerden net zo veel problemen als Nederlandse kinderen. Migrantenouders rapporteerden bij hun kinderen meer psychosomatische klachten, angsten en andere storende gedachten (o.a. waandenkbeelden en dwangmatige gedachten) dan Nederlandse ouders. De mate waarin externaliserende problemen werden genoemd verschilde niet tussen immigranten en Nederlanders. Leerkrachten rapporteerden voor immigrantenkinderen meer delinquent gedrag, maar minder angstproblemen en minder sociale problemen dan voor Nederlandse kinderen. In hoeverre deze bevindingen nu werkelijk iets zeggen over de prevalentie van probleemgedrag bij kinderen uit verschillende culturele groepen in Nederland, is op basis van het voorgaande onderzoek niet te beoordelen. Hier is duidelijk sprake van een probleem dat in paragraaf 8.5 nog verder wordt besproken, namelijk een probleem met de validiteit van oordeelsvorming.

Reijneveld, Harland, Brugman, Verhulst en Verloove-Vanhoorick (2005) voerden een studie uit op basis van oordelen van schoolartsen en schoolverpleegkundigen over de prevalentie van psychosociale problemen bij 4098 kinderen tussen vijf en zestien jaar. In aanvulling op het oordeel van deze professionals vulde één van de ouders van de kinderen een vragenlijst in (de CBCL-ouderversie). Er deden 3570 Nederlandse kinderen mee, 101 kinderen uit Suriname of de Nederlandse Antillen, 91 Turkse of Marokkaanse kinderen, 200 kinderen uit andere niet-geïndustrialiseerde landen en 136 kinderen uir andere westerse landen. De onderzoekers maakten geen onderscheid binnen de genoemde groepen (Surinamers werden niet onderscheiden van Antillianen en Turken niet van Marokkanen). Zij stelden vast dat de artsen en verpleegkundigen hogere scores voor psychosociale problemen rapporteerden voor Turkse en Marokkaanse kinderen dan voor de andere groepen. Turkse en Marokkaanse ouders rapporteerden meer internaliserende problemen voor hun kinderen dan ouders van Nederlandse kinderen. Surinaamse en Antilliaanse ouders rapporteerden een hogere algemene probleemscore voor hun kinderen dan ouders uit andere groepen. Ouders en de professionals zijn het eens over de betere psychosociale ontwikkeling van autochtone kinderen, maar over de allochtone kinderen verschillen ze van. mening.

Tot dusver zijn onderzoeken besproken waaraan kleine aantallen migrantenjongeren deelnamen. Er zijn ook enkele onderzoeken uitgevoerd waaraan grotere aantallen Turkse en Marokkaanse jongeren deelnamen om een beter groepspecifiek beeld van deze jongeren te krijgen. In 1993 en 1994 werd in Rotterdam en Den Haag een onderzoek uitgevoerd naar emotionele en gedragsproblemen onder een voor die steden representatieve groep van 833 Turkse jeugdigen van vier tot achttien jaar. In 2001 en 2002 werd, wederom in Rotterdam en Den Haag een vergelijkbaar onderzoek uitgevoerd, maar dan onder 819 Marokkaanse jeugdigen. De onderzoekers hebben de gegevens van deze twee groepen vergeleken en daaraan ook nog een grote Nederlandse vergelijkingsgroep ( 2227 jeugdigen) toegevoegd, afkomstig van een eerdere representatieve studie in 89 gemeenten (Stevens, Pels, Vollebergh, Bengi-Arslan, Verhulst \& Crijnen, 2005). Ook in deze studie werden gegevens verzameld bij de jeugdigen zelf (11 jaar en ouder), bij de ouders en leerkrachten. Turkse en Nederlandse jongeren rapporteerden zelf meer externaliserende problemen dan de Marokkaanse jongeren. De leerkrachten 
echter waren van oordeel dat Marokkaanse jongeren meer externaliserende problemen hadden dan Nederlandse en Turkse jongeren. De Marokkaanse ouders rapporteerden even weinig externaliserende problemen voor hun kinderen als de Turkse en Nederlandse ouders voor hun kinderen. Turkse ouders en Turkse jongeren zelf (alleen de elf- tot achttienjarigen) rapporteerden meer internaliserende problemen dan ouders en de jongeren uit de andere twee groepen. Leerkrachten zagen wat betreft internaliserende problemen geen verschil tussen de groepen.

Relatief veel onderzoek is gedaan naar jeugdige immigranten en criminaliteit. Het meest bekend is de oververtegenwoordiging van Antilliaanse en Marokkaanse jongeren in de justitiële criminaliteitsregisters (Kromhout \& Van San, 2003). Uit die registers is op te maken dat Antillianen verhoudingsgewijs meer betrokken zijn bij ernstige geweldsmisdrijven en Marokkanen meer bij vermogensdelicten. Deze oververtegenwoordiging zou te maken kunnen hebben met selectiviteit of discriminatie bij politie en rechterlijke macht. Een belangrijke aanwijzing dat dit niet zo is wordt gevonden in vragenlijstonderzoek onder veertien- en vijftienjarige jongeren waarin diezelfde oververtegenwoordiging is vastgesteld (Junger-Tas, Cruijff, van de Looij-Jansen \& Reelick, 2003). De oververtegenwoordiging blijft ook in stand als rekening wordt gehouden met de sociaaleconomische leefsituatie van de jongeren (Borghans \& Ter Weel, 2003).

Dit hoofdstuk richt zich speciaal op de invloed van acculturatie op het optreden van sociale en emotionele problemen. Hiervoor is beschreven dat het voor het bepalen van de invloed van acculturatie van belang is na te gaan of er tussen bevolkingsgroepen, voorafgaand aan emigratie, sprake is van verschillende prevalenties in het optreden van probleemgedrag. Er was slechts één studie te vinden waarin dit was onderzocht in voor de Nederlandse situatie relevante groepen en wel in Suriname (Selten, Zeyl, Dwarkasing, Lumsden, Kahn \& Van Harten, 2005). De onderzoekers stelden vast dat de kans op schizofrenie bij volwassen Surinamers in Suriname beduidend lager was dan bij Surinaamse immigranten in Nederland en betoogden dat de verhoogde kans in Nederland waarschijnlijk samenhangt met de leefomstandigheden in Nederland. De auteurs specificeren dit nog een beetje door te wijzen op de competitieve, stressvolle aard van het stadsleven.

In de meeste landen van herkomst van de in Nederland woonachtige immigranten is geen zorgvuldig en representatief onderzoek uitgevoerd om na te gaan welke kans leden van de bevolking hebben om een afwijkende psychische ontwikkeling door te maken. Dit gebrek aan gegevens over de kans op een problematische ontwikkeling bij leden van een culturele groep die niet emigreren, maakt het des te moeilijker om te bepalen of het optreden van een afwijkende ontwikkeling bij immigranten wordt verklaard door hun acculturatie. Los van de vraag of probleemgedrag meer of minder voorkomt bij autochtonen of allochtonen is het voor het signaleren, de preventie en het remediëren van probleemgedrag van belang om te weten of er bij het ontstaan, de ernst en de duur van de problemen sprake is van culturele specificiteit of van invloed van acculturatieprocessen.
8.3 Risico- en beschermende factoren

Als de kans bekend is die leden van een bepaalde etnische of culturele groep lopen op een afwijkende ontwikkeling, dan is het voor preventie en behandeling van belang om na te gaan bij welke persoonskenmerken en onder welke omgevingsomstandigheden de kans toeneemt dat de afwijkende ontwikkeling ook werkelijk optreedt (risicofactoren) of, bij aanwezigheid van risicofactoren, juist niet toeneemt doordat de invloed van risicofactoren wordt verminderd of zelfs geneutraliseerd door beschermende factoren. Uitspraken over een verhoogde of verminderde kans op problemen zijn altijd gebonden aan onderzoek binnen bepaalde groepen personen en zijn niet zonder meer van toepassing op individuen. Het aanwezig zijn van risicofactoren leidt niet als vanzelf bij elke persoon tot problemen. Bovendien is op basis van de aanwezigheid van bepaalde risicofactoren veelal niet te voorspellen tot welk specifiek probleem dit kan leiden.

In de literatuur zijn vele beschermende en risicofactoren genoemd.

Kromhout en Van San (2003) noemen als algemene risicofactoren voor immigranten onder meer het leven in achterstandswijken, het ontbreken van een sociaal netwerk, te weinig leren op school, foute vrienden en verkeerd vrijetijdsactiviteiten. Als meer specifieke risicofactoren worden genoemd de vluchtgeschiedenis, langdurige asielprocedures, cultuurverschillen tussen school en thuis (bijv. taal) en conflicten tussen ouders en jeugdigen. Als beschermende factoren worden genoemd een hoge opleiding van de ouders, een gering cultuurverschil tussen het gezin en de Nederlandse samenleving, een bewuste opvoeding en controle op de schoolprestaties, de aanwezigheid van een sociaal netwerk en steun vanuit de eigen etnische gemeenschap. Van het van, 2003). Doorgaans, echter, hebben personen met verschillende factoren te maken. Naar het relatieve belang van combinaties van deze factoren bij de" ontwikkeling van afwijkend gedrag is nog nauwelijks systematisch onderzoek gedaan.

In de volgende paragraaf wordt verder ingegaan op conflicten tussen ouders en jongeren, omdat dit een ingewikkelde factor is waarvan niet duidelijk is in welke mate werkelijk sprake is van een acculturatiegebonden verschijnsel. In box 8.2 wordt daarnaast ingegaan op een heel bijzondere, verschijnsel. In box 8.2 wordt daarnaast ingegaan op een hel bulisurgebonden en moreel beladen risicofactor: neef-nichthuwelijken.

Ouder-kindconflicten

Onenigheden tussen ouders en kinderen is eigen aan het opgroeien va jongeren in alle culturen (Dekovic, 1999; Fuligny, 1998). Toch gaan acculturatieonderzoekers er doorgaans van uit dat in immigrantengezinnen sprake is van extra problemen op dit gebied. Immigrantenouders zouden er minder goed dan autoch tone ouders in slagen om hun waarden omtrent het gezin en de verantwoordelijkheden van hun kinderen over te dragen op hun kinderen (Tseng \& Lam, 1999; Phalet \& Schönpflug, 2001). Een mogelijke reden is dat 
immigrantenjongeren zich sneller aanpassen aan de nieuwe leefomgeving dan hun ouders. Jongeren gaan naar school en komen daar in contact met de gewoonten en waarden van de autochtone gemeenschap. Door de druk van de school en van hun leeftijdgenoten gaan ze in hun eigen gewoonten en waarden steeds meer lijken op de autochtone gemeenschap. Ouders hebben veel minder mogelijkheden om in contact te komen met de gewoonten en waarden van de nieuwe samenleving en zijn doorgaans ook minder vaardig in de nationale taal van die samenleving. Door dit verschil in acculturatiesnelheid tussen ouders en hun kinderen zou er meer onenigheid zijn in migrantengezinnen over de verantwoordelijkheden en verplichtingen van de kinderen in het gezin. Die onenigheid zou aanleiding zijn tot spanningen die op hun beurt een negatieve invloed zouden hebben op het welbevinden en het sociale gedrag van de jongeren (Buriel \& De Ment, 1997; Kwak, 2003; Phinney \& Vedder, 2006). Vedder en Oortwijn (2007) deden onderzoek bij 151 Turkse, 90 Hindoestaans-Surinaamse en 95 autochtone gezinnen in Nederland. In de Turkse en Surinaamse gezinnen waren de scores voor verantwoordelijkheden en verplichtingen in het gezin (voorbeelditems waren: Kinderen dienen hun ouders te gehoorzamen. Ouders moeten hun kinderen leren zich netjes te gedragen. Kinderen moeten voor hun ouders zorgen als ze hulpbehoevend worden.) van zowel de ouders als de jongeren hoger dan die van Nederlandse ouders en jongeren. Dit duidt op een culturele invloed. In alledrie de groepen waren de ouders van oordeel dat jongeren meer verantwoordelijkheden en verplichtingen hadden in het gezin dan de jongeren zelf. De grootte van deze discrepantie verschilde niet tussen de drie groepen. De veronderstelling dat het verschil in acculturatiesnelheid tussen ouders en kinderen invloed zou hebben op intergenerationele discrepantiescores werd niet bevestigd. Kortom, dit onderzoek vond weinig aanwijzingen voor de invloed van acculturatie op de relatie tussen onenigheid tussen ouders en hun kinderen en het psychische functioneren van de kinderen. Opvallend is dat de onenigheid tussen ouders en jongeren geen samenhang vertoonde met de mate van onaangepast gedrag van de jongeren.

\section{Box 8.2 Neef-nichthuwelijk}$$
\text { the }
$$

Het neef-nichthuwelijkis een voorbeeld van een risicofactor met een biologische basis. in neef-niththuwelijken kont nadrukkelijk de verbondenhejd van biologische en culturelé processen tôt viting. In Nederłand komen neefnichthuwelijken vooral voor bif Turken en Marokkanen, maar ook onder de autochtone Nederlandse bevolking komt het voor, zij het in lage percentages. Neef-nichthuwelijken, of meer algemeen huwelijken tussen verwanten, zijn omkingd met een was van 'stecht en ongezond'. Dit maakt het des te belangrijker om een juist beeld te schetsen.

Veel Marokkaanse en Turkse jangeren zoeken een partner binnen de eigen etnische groep en zelfs vaak in het land van herkomst. Dergelijke huwelijken zïn juist vanuit de herkomstlanden gewild, omdat deze de mogelijkheid bieden tot legale immigratie. Bij het regelen van die huwelijken wordt daarom waar mogelijk druk uitgeoefend vanuit het herkomstland. Personen die dat het best kunnen behoren tot de eigen familie of wonen in de gemeenschap waarvandaan ook het gezin naar Nederland is geëmigreerd (Lindo, 1996). Hoeveel neef-nichthuwelijken plaatsvinden in diverse etnische groepen is onbekend, aangezien dit in Nederland niet geregistreerd wordt.

Traditioneel komen neef-nichthuwelijken veel voor in de Arabische wereld. Khlat (1996) rapporteerde dat er in 1992 in Marokko tweeëntwintig procent neef-nichthuwelijken en zeven procent huwelijken tussen andere verwanten waren. Dergelijke percentages blijven bestaan ondanks dat het bewustzijn groeit dat een dergelijke verbintenis een verhoogd gezondheidsrisico inhoudt voor de kinderen. Een verklaring wordt wellicht gegeven door sociale en economische voordelen. Neef-nichthuwelijken worden gezien als een mogelijkheid om het familiebezit veilig te stellen. Verder wordt ervan uitgegaan dat familieleden elkaar al kennen en dat dit helpt om eventuele conflicten omtrent en binnen het huwelijk te voorkomen of te reguleren. in relatie tot migreren komt daar nog bij de mogelijkheid van de migrant en de achterblijvende familie om het economische toekomstperspectief drastisch te verbeteren (Eldering, 2006):

Zoals gezegd leveren neef-nichthuwelijken een verhoogd gezondheidsrisico op voor de kinderen die uit deze huwelijken voortkomen. Daarbij gaat het onder meer om een verhoogd risico op mentale en fysieke handicaps (Teebi \& Farag, 1996). Overigens is dat risico niet zo-heel groot. Het risico van een effelijk bepaalde aandoening vanaf de geboorte is in de Nederlandse populatie ongeveer drie procent (bij) samenlevingsverbanden waarin zwangerschappen optreden). Bij neef-nichthuwelijken is dit verhoogd met ongeveer een procent (wwwerfelijkheid.nl/documentatie/interviews/giordano.php, interview met klinisch geneticus Piero Giordano, Lejds UMC). Deze verhoging komt voor rekening van recessieve aandoeningen, Dit zijn aandoeningen veroozaakt doordat de ouders van het kind hetzelfde gendefect. van hun eigen gezamenijike ouders hebben geërfd. Bennett en collega's (2002) verduidelijken dat er bij de bepaling van het risico ook rekening dient të worden gehouden met de omstandigheid dat neef-nichthuweiliken doorgaans voorkomen in een germeenschap die al gedurende een lange periode gekenmerkt is door het krijgen van kinderen in relaties van verwanten. wardoor zich in een groep schadelijke genmutaties hebben kunnen concentreren. Dit verhoogt het risico boven de genoemde procent Kortom, het gaat om een dynamisch proces dat wat betreft de werking en gevolgen aanhoudend vraagt on risico-onderzoek. In algemene zin kan worden opgemerkt dat die verhoogde concentratie genmutaties lejdt tot een verhoogde kans op doodgeboortes, afwijkingen bij de geboorte en afwijkende lichamelijke en geestelijke ontwikkeling in thet latere leven. 


\subsection{Verklarende mechanismen}

Van veel verschijnselen die uiting zijn van een afwijkende ontwikkeling is de oorzaak niet precies bekend. In algemene zin zijn er wel een aantal mechanismen of omstandigheden te beschrijven die als oorzaak zijn aan te duiden. In box 8.2 is al gewezen op erfelijkheid of een aangeboren predispositie als grond voor het ontstaan van psychische problemen. In deze paragraaf wordt nog ingegaan op stress samenhangend met emigratie en op onderwijs- en opvoedingsgerelateerde stress.

Acculturatie; emigratiestress

In Nederlandse studies naar de prevalentie van internaliserend en externaliserend probleemgedrag en van psychopathologie in migrantengroepen wordt uitgegaan van de stresshypothese (vgl. Stevens e.a., 2005). De emigratie zelf is stressvol doordat vertrouwde sociale relaties worden achtergelaten en een onzekere toekomst opdoemt. De immigrant moet in een nieuwe, niet-vertrouwde omgeving nieuwe taken uitvoeren, kan niet terugvallen op cultuur- en omgevingsgebonden routines en moet communiceren in een taal die onvoldoende wordt beheerst. De stress zal nog toenemen als er in de nieuwe situatie discriminatie wordt ervaren in plaats van steun en begrip. De resulterende stress kan zodanig groot worden dat de mentale weerbaarheid van personen afneemt (vgl. Jasinskaja-Lahti, Liebkind \& Vesala, 2002; Sellers \& Shelton, 2003) en er in toenemende mate sprake is van problematisch psychisch en sociaal-emotioneel functioneren (Liebkind, Jasinskaja-Lahti \& Solheim, 2004; Shrake \& Rhee, 2004). Voor de Nederlandse situatie lieten Vedder en Van de Vijver (2003) zien dat ervaren discriminatie bij migrantenjongeren leidde tot slechtere sociale aanpassing en minder welbevinden, minder contact met autochtone Nederlanders, een minder sterke geneigdheid om te integreren en een sterkere etnische identiteit. Dit maakt hen kwetsbaarder, doet hen minder optimaal functioneren (bijv. meer ziek, meer werkloos) wat vervolgens weer voeding geeft aan discriminatie en het gevoel daarvan slachtoffer te zijn. Discriminatie maakt de banden met de meerderheid zwakker en de banden met de eigen groepen hechter.

Acculturatie; onderwijs- en opvoedingsstress

In box 8.1 is het proces van immigratie beschreven en het niet langer functioneel zijn van bepaalde gewoonten, eerder geleerde kennis en vaardigheden. Voor veel migranten is de migratie gekoppeld aan een verlangen naar een goed leven in de nieuwe samenleving en de daaraan gekoppelde taak om in een relatief korte tijd nieuwe, tot dan onbekende kennis en vaardigheden te leren. Migrantenkinderen worden bijvoorbeeld geacht een onderwijsprogramma in het Nederlands te kunnen volgen. Dit betekent dat ze eerst de Nederlandse taal moeten leren. Daarnaast blijven hun ouders en andere leden van hun etnische groep het van belang vinden dat ze ook hun weg weten te vinden in de eigen groep. Kortom, hun leertaak is omvangrijker dan die van autochtone leeftijdgenoten. Verder geldt voor een deel van deze kinderen dat de omstandigheden waaronder ze de omvangrijke leertaak moeten klaren ongunstig zijn. Thuis worden ze weinig gesteund, omdat ouders niet weten hoe ze dat kunnen doen of omdat ouders zelf te druk zijn met allerlei andere zaken. Het gaat hier om risicofactoren. Het zijn niet zozeer afzonderlijke risicofactoren die een grote impact hebben op de thuissituatie en op het leren van kinderen, maar een combinatie van factoren. Sameroff, Seifer, Baldwin en Baldwin (1993) bijvoorbeeld, onderscheidden tien factoren die een negatieve invloed hebben op de cognitieve ontwikkeling, zoals lage opleiding van ouders, werkloosheid, laag inkomen, psychische problemen van de ouders, eenoudergezin, mar ook het behoren tot een etnische minderheidsgroep. Ze lieten in hun studie zien dat de cognitieve prestaties van kinderen duidelijk afnamen als er thuis sprake was van tenminste twee risicofactoren. De onderzoekers lieten ook zien dat het wegnemen van risicofactoren een positieve invloed heeft op de ontwikkeling van kinderen. Ter verklaring stelden zij dat gezinnen beschikken over 'verborgen' voorraden aan kennis en vaardigheden om kinderen op te voeden. Deze kunnen niet gebruikt worden zolang alle tijd en energie van opvoeders in beslag wordt genomen door het omgaan met spanningen en bedreigingen in de omgeving en in het gezin. Het effect is dat kinderen minder leren en zich minder gunstig ontwikkelen, waardoor hun maatschappelijke kansen afnemen.

\subsection{Assessment, diagnostiek en de validiteit van} oordeelsvorming

In het voorgaande is verduidelijkt dat het vaststellen van de prevalentie van stoornissen en probleemgedrag beoordelingen vergen en dat deze beoordelingsprocessen en de criteria die daarbij worden gebruikt tussen personen variëren. Hiervoor werd onderzoek aangehaald waaruit bleek dat Marokkaanse ouders van oordeel waren dat hun kinderen niet vaker werden gekenmerkt door gedragsproblemen dan kinderen uit andere etnische groepen, terwijl de leerkrachten van deze Marokkaanse kinderen juist meer gedragsproblemen rapporteerden. Dit verschil in beoordeling kan samenhangen met verschillen in waarneming tussen ouders en leerkrachten en met verschillen in interpretatie van het gedrag, of een combinatie van beide. Het verschil in waarnemen kan bepaald worden door de verschillende situaties waarin ouders en leerkrachten het gedrag van de kinderen waarnemen. Ouders zien hun kinderen vooral thuis en leerkrachten op school. Het verschil in waarneming kan ook samenhangen met de verschillende expertise van ouders en leerkrachten. Immers, leerkrachten zijn in meer of mindere mate getraind om kinderen systematisch te observeren, ouders doorgaans niet. Het verschil in waarneming kan bovendien samenhangen met de verschillende instrumenten die worden gebruikt of met verschillen in kennis van hoe de instrumenten betrouwbaar moeten worden afgenomen. Bij instrumenten kan worden gedacht aan vragenlijsten, een semi-gestructureerd 
interview of aan een observatieprotocol. Dat verschillende personen verschillend rapporteren over een en dezelfde persoon is op zichzelf geen probleem. Ze laten wellicht verschillende kanten van de persoon zien en hun waarnemingen kunnen betrekking hebben op uiteenlopend gedrag van de persoon in verschillende contexten. In deze gevallen kunnen de verschillende bijdragen van verschillende personen een meer omvattend, rijker beeld opleveren op basis waarvan een betere diagnose kan worden gesteld dan op basis van informatie van minder informanten.

Het interpretatieprobleem hangt samen met verschillen tussen personen in waarden, normen en ervaringen met bepaalde gedragingen. Wat voor de ene persoon afwijkend gedrag is, is dat voor een ander niet noodzakelijkerwijs en wat de een als stuurbaar gedrag ziet, is voor de ander dusdanig onhanteerbaar dat de politie of andere hulpverleners erbij worden geroepen. Box 8.3 bevat een voorbeeld.

\section{Box 8.3 Agressiviteit bij Antilliaanse jongeren}

Kromhout en Vedder (1996) verduidelijkten dat de interpretatie van bazig en agressief gedrag verschilt tussen Antilliaanse en Nederlandse jongeren en Nedertandse leerkrachten. Antilliaanse jongens hanteren een beeld van goed sociaal gedrag waarin ook stoer doen en de baas spelen een gerespecteerde plaats hebben. Deze waardering wordt versterkt door hun opvoeding en leefomgeving waarin machismogedrag positief wordt gewaardeerd. Bij machismogedrag gaat het om een combinatie van kameraadschap, luidruchtigheid, een nadruk op fysieke verschijning en fysiek vertoon om uiting te geven aan een notie van mannelijkheid. Voor ouders en andere Antilliaanse kinderen wordt dergelijk gedrag in mindere mate als storend ervaren en beoordeeld vergeleken met Nederlandse leerkrachten en Nederlandse leeftijdgenoten. Die verschillende interpretaties van hetzelfde gedrag hebben tevens verschillende implicaties. Agressieve kinderen worden in westerse landen veelal door andere kinderen veroordeeld en gemeden. Agressieve kinderen kunnen daardoor in een sociaal isolement geraken. In een groep Antilliaanse kinderen is dit niet of in mindere mate het geval. De betekenis van deze verschillen voor de verdere ontwikkeling van Antilliaanse jongens is onvoldoende onderzocht, maar het is aannemelijk dat het van invloed is op de voorkeur van de jongens voor sociale contacten binnen de eigen groep. Als dit het gevolg is, dan groeien ze op met gemiddeld meer agressief gedrag en verloopt hun acculturatie vertraagd. Hierdoor topen ze een verhoogde kans op psychische en gedragsproblemen.

Interpretatieproblemen kunnen aanleiding zijn tot problemen in de hulpverlening. Goede hulpverleners maken bij het gebruik van tests, vragenlijsten en andere hulpmiddelen die worden gebruikt voor verschillende culturele groepen, maar er niet voor zijn ontwikkeld, aannemelijk dat de cliënt baat heeft bij het gebruik en er in ieder geval niet door wordt benadeeld.
Juist in dit soort situaties dienen hulpverleners ervan doordrongen te zijn dat zij er zijn ten dienste van de cliënten. Kortmann (2006) stelt voor dat hulpverleners, gegeven de beperkte bruikbaarheid van beschikbare vragenlijsten en gestandaardiseerde interviews voor cliënten die onvoldoende bekend zijn met de 'meerderheidscultuur', nog meer dan bij Nederlandse of Vlaamse cliënten op zoek moeten naar informatie van personen uit het sociale netwerk van de cliënten. Hoe beschrijven en interpreteren zij het gedrag? Wat vinden zij gewoon en afwijkend gedrag en welke mogelijkheden tot hulp zien zij? Ook kan in het sociale netwerk van cliënten aandacht worden geschonken aan de kennis van de meerderheidscultuur om in te schatten of beschikbare gestandaardiseerde diagnostische instrumenten toch een rol kunnen spelen bij het analyseren van de problemen en hulpverleningsmogelijkheden van en voor cliënten. Overigens betekent dit dat de hulpverlener de uitdaging moet aangaan om meer kennis en competenties te ontwikkelen die nodig zijn voor het begrijpen van de betekenis van diverse culturen voor de leefwerelden van diens klanten. Bovendien betekent dit dat er niet simpel kan worden gesteld dat instrumenten zoals de hiervoor veel aangehaalde CBCL wel of niet gebruikt kunnen worden. Wel kan worden gesteld dat gebruik los van het kennen van de culturele achtergrond van de klanten onverstandig is, de kwaliteit van de diagnose bedreigt en de behandeling vervolgens bemoeilijkt.

\subsection{Conclusie en toekomstperspectief}

Doel van dit hoofdstuk was om een beeld te schetsen van acculturatie en afwijkende ontwikkeling en om na te gaan of er reden is om in het kader van de geestelijke gezondheidszorg speciale aandacht te schenken aan immigranten en hoe dat dan het beste kan. Onderzoek maakt aannemelijk dat er bij verschillende etnische groepen in Nederland sprake is van een verschillende kans op specifieke vormen van afwijkende psychische ontwikkeling. Belangrijk daarbij is vast te stellen dat er niet eenvoudig sprake is van minder problemen bij autochtone Nederlanders en meer problemen bij migranten. De beschreven studies wijzen op relatief meer problemen in de Marokkaanse groep en minder in de Turkse groep. Bovendien is verduidelijkt dat de verschillen tussen etnische groepen gerelateerd zijn aan specifieke problemen. Bij Marokkanen en Surinamers is sprake van een hogere prevalentie van schizofrenie dan in andere groepen en bij Marokkaanse en Antilliaanse jongeren, vooral jongens, is sprake van hogere niveaus van gedragsproblemen dan bij hun leeftijdgenoten uit andere groepen. Verder blijkt dat er sprake is van groepsspecifieke risicofactoren, zoals neef-nichthuwelijken. Al deze verschillen tussen groepen vormen een reden om inderdaad in het kader van de geestelijke gezondheidszorg speciale aandacht te schenken aan immigranten. Dit betekent tevens dat er speciale, want andere, aandacht dient te worden geschonken aan de autochtone groep. Op dit moment houdt deze vraag naar groepsspecifieke aandacht vooral een uitdaging in om na te gaan wat dit kan betekenen voor diagnostiek, pre- 
ventie en interventie; een uitdaging, omdat er nog weinig aangepaste middelen beschikbaar zijn, laat staan op effectiviteit onderzocht zijn. Wel worden belangrijke aanzetten gegeven om te komen tot vroegtijdige signalering, preventieve interventies in risicogroepen en beter georganiseerde duurzame aandacht voor risicogroepen en reeds behandelde personen. In recente adviezen aan de regering worden bijvoorbeeld specifieke interventies genoemd en worden zelfs instrumenten genoemd voor het signaleren van ontwikkelings- en opvoedingsproblemen (vgl. Doorten \& Rouw, z006; Hermanns, Öry \& Schrijvers, 2005). In beide adviezen wordt echter nauwelijks gerept over migrantenkinderen of migrantengezinnen of over de noodzaak om de validiteit van de adviezen te onderzoeken voor diverse culturele groepen. Dit doet niets af aan de waarde van de algemene adviezen. Het eerste is om vroegtijdig te signaleren, dat systematisch en populatiebreed te doen zonder moeilijk bereikbare of anderstalige gezinnen uit te sluiten. Het tweede is om gezinnen zoveel mogelijk te betrekken bij het signaleren en niet blind te varen op het oordeel van professionals die verhoudingsgewijs weinig contact hebben met het kind en de opvoedingsomstandigheden niet kennen, zoals een peuterleidster of een arts of verpleegkundige van het consultatiebureau. Ten slotte wordt geadviseerd om uitsluitend te werken met beproefde interventies, om de kans op succes zo groot mogelijk te laten zijn.

In dit hoofdstuk gaat het om de samenhang tussen immigratie en afwijkende ontwikkeling. Aangegeven is dat psychische en gedragsproblemen van migranten zowel kunnen samenhangen met problemen die al bestonden voorafgaand aan de migratie, als met problemen die zijn veroorzaakt of versterkt door de immigratie en de levensomstandigheden in de nieuwe samenleving. Dit hoofdstuk heeft zich vooral gericht op de problemen die ontstaan door immigratie en de veranderde levensomstandigheden daarna. Voor de meeste migranten heeft de migratie geen negatieve gevolgen voor hun welbevinden en sociale gedrag. Voor een kleine groep is sprake van ernstige gevolgen. Vooral het verlies van binding met de eigen groep en de ervaring gediscrimineerd te worden blijken samen te hangen met problemen. Dit is opmerkelijk omdat hiermee wordt gesuggereerd dat preventicmaatregelen, naast een uitdaging gericht op individuele migranten, in ieder geval ook een maatschappelijke uitdaging inhouden. Dit is temeer het geval nu blijkt dat er in toenemende mate ongeduld valt te bespeuren ten aanzien van de snelheid waarmee migranten zich aanpassen aan gewoonten, normen en waarden die kenmerkend worden geacht voor de Nederlandse samenleving (zie Arends-Tóth, 2003). Maar bovendien omdat er sprake is van voortschrijdende etnische segregatie van vroegkinderlijke opvangvoorzieningen, scholen en buurten, waardoor de mogelijkheden afnemen voor positieve interacties tussen allochtonen en autochtonen (Gijsberts \& Dagevos, 2005).

Ten slotte, ook de eerder beschreven bevinding dat oordelen over het psychische welbevinden en het sociale gedrag van immigrantenjongeren sterk verschillen afhankelijk van wie het oordeel geeft, is aanleiding voor bezinning op aangepaste manieren van signaleren, voorkomen en remedië- ren van problemen. Als een leerkracht bij een Marokkaanse kleuter in verhoogde mate agressief en verstorend gedrag waarneemt, is dat dan voldoende als basis voor het signaleren van een mogelijk afwijkende ontwik-

keling en het in gang zetten van maatregelen om het storende gedrag tegen te gaan, terwijl bekend is dat ouders en leeftijdgenoten dat gedrag heel anders waarderen? Het is aannemelijk dat het voor de ontwikkeling van kinderen en jongeren beter is als niet slechts professionals, maar ook leeftijdgenoten en opvoeders het met elkaar eens zijn over het al of niet aanwezig zijn van storend gedrag en de noodzaak daaraan iets te doen. Voor de effectiviteit van eventuele remediërende en beschermende activiteiten lijkt het zelfs van groot belang dat ouders en vrienden hun bijdrage daaraan leveren. Kortom, onenigheid tussen betrokkenen over de validiteit van de oordeelsvorming rond het gedrag en de ontwikkeling van kinderen en jongeren dient zelf inzet te zijn van overleg om tot meer eensluidende oordelen te komen en tot een afstemming van verantwoordelijkheden voor de zorg, opvoeding en hulpverlening aan die kinderen of jongeren.

\section{Literatuur}

Arends-Tóth, J.V., \& Vijver, F.J.R. van de (2003). Multiculturalism and acculturation: views of Dutch and Turkish-Dutch. European Journal of Social Psychology, 33, 249-266.

Bennett, R., Motulsky, A., Bittles, A., Hudgins, L., Uhrich, S., Doyle, D., Silvey, K., Scott, C.R., Cheng, E., McGillivray, B., Steiner, R., \& Olson, D. (2002). Genetic counseling and screening of consanguineous couples and their offspring: recommendations of the national society of genetic counselors. Journal of Genetic Counseling, 11, 97-119. Berry, J.W. (1980). Acculturation as varieties of adaptation. In A. Padilla (Ed.), Acculturation: theory, models and some new findings (pp. 9-25). Boulder: Westview.

Berry, J., Phinney, J., Sam, D., \& Vedder, P. (2006). Immigrant youth in cultural transition; acculturation, identity and adaptation actoss national contexts. Mahwah, NJ: Lawrence Erlbaum Ass.

Bleichrodt, N., \& Vijver, F. van de (2001). Diagnostiek bij allochtonen; mogelijkheden en beperkingen van psychologische tests. Lisse: Swets \& Zeitlinger.

Borghans, L., \& Weel, B. ter (2003) Criminaliteit en etniciteit. Economisch Statistische Berichten, 88 (4419), 548-550.

Buriel, R., \& Ment, T. de (1997). Immigration and sociocultural changes in Mexican, Chinese, and Vietnamese families. In A. Booth, A. Crouter \& $\mathrm{N}$. Landale (Eds.), Immigration and the family: research and policy on U.S. immigrants (pp. 165-200). Mahwah, N]: Lawrence Erlbaum.

Dekovic, M. (1999). Parent-adolescent conflict: possible determinants and consequences. International Journal of Behavioral Development, 23 (4), 997-1000.

Doorten, I., \& Rouw, R. (2006) Opbrengsten van sociale investeringen. Amsterdam: SWP. Eldering, L. (2006). Cultuur en opvoeding. Rotterdam: Lemniscaat.

Fuligni, A. (1998). Authority, autonomy, and parent-adolescent relationships: a study of adolescents from Mexican, Chinese, Filipino, and European backgrounds. Developmental Psychology, 34, 782-79z. 
Gijsberts, M., \& Dagevos, J. (2005) Uit elkaars buurt. De invloed van etnische concentratie op integratic en beeldvorming. Den Haag: SCP.

Graaf, R. de, Have, M. ten, Dorsselaer, S. van, Schoemaker, C., \& Vollebergh, W. (2004). Etniciteit in onderzoek naar psychische stoornissen. Utrecht: Trimbos.

Graaf, R. de, Have, M. ten, Dorsselaer, S. van, Schoemaker, C., Beekman, A., \& Vollebergh, W. (2005) Verschillen tussen ernische groepen in psychiatrische morbiditeit. Maandblad Geestelijke Volksgezondheid, $60(7 / 8), 703-717$.

Hermanns, J., Öry, F., \& Schrijvers, G. (2005). Helpen bij opgroeien en opvoeden: eerder, sneller en beter. Een advies over vroegtijdige signalering en interventies bij opvoed-en opgroeiproblemen. Utrecht: Julius Centrum.

Herskovits, M., Linton, R., \& Redfield, R. (1936) Memorandum on the Study of Acculturation. American Anthropologist, 38 (1), 149-152.

Jasinskaja-Lahti, I., Liebkind, K., \& Vesala, T. (2002). Rasismi ja syrintä Suomessa. Maahan muttajien kokemukset (Racisme en discriminatie in Finland. De ervaring van immigranten). Helsinki: Gaudeamus.

Junger-Tas, J., Cruijff, M., Looij-Jansen, P. van de, \& Reelick, F. (2003). Etnische minderheden en het belang van binding. Een onderzoek naar anti-sociaal gedrag van jongeren. Den Haag: SDUuitgevers.

Khlat, M. (1996). Endogamy in the Arab world. In A.S. Teebi \& T.I. Farag (Eds.), Genetic disorders among Arab populations (pp. 63-80). New York and Oxford: Oxford University Press.

Kortmann, F. (2006). Transculturele psychiatrie. Assen: Van Gorcum.

Kromhout, M., \& San, M. van (2003). Schimmige werelden : nicuwe etnische groepen en jeugdcriminaliteit. Den Haag: Boom.

Kromhout, M., \& Vedder, P. (1996). Culrural inversion in children from the Antilles and Aruba in the Netherlands. Anthropology and Education Quarterly, 27, 568-586.

Kwak, K. (2003). Adolescents and their parents: a review of intergenerational family relations for immigrant and non-immigrant families. Human Development, 46, 115-136.

Levecque, K., Lodewyckx, I., \& Eeden, S. van den (2006), Gezondheid en gezondheidszorg bij allochtonen in Vlaanderen. Antwerpen/Hasselt: Steunpunt Gelijkekansenbeleid.

Levecque, K., Lodewyckx, I., \& Vranken, J. (2007). Depression and generalized anxiety in the general population in Belgium: a comparison between native and immigrant groups. Journal of Affective Disorders, 97, 229-239.

Liebkind, K., Jasinskaja-Lahti, I., \& Solheim, E. (2004). Cultural identity, perceived discrimination and parental support as determinants of immigrants' school adjustment: Vietnamese youth in Finland. Journal of Adolescent Research, 19 (6), 635-656.

Lindo, F. (1996). Maakt cultuur verschil? De invloed van groepsspecifieke gedragspatronen op de onderwisloopbaan van Turkse en Iberische migrantenjongeren. Amsterdam; Het Spinhuis. Lucassen, L. (2006). Gelijkheid en onbehagen, de wortels van het integratiedebat in West-Europa. Oratie. Leiden: Universiteit Leiden.

Müller, H.P. (2006). Local traditions in global competition. http://www.ethno.unizh.ch/mitarbeiterinnen/profiles/folder_hpm/global_competition/global_competition.html (retrieved, September 15th, 2006)

Phalet, K., \& Schönpflug, U. (2001). Intergenerational transmission of collectivism and achievernent values in two acculturation contexts: the case of Turkish families in Ger- many and Turkish and Moroccan families in the Netherlands. Journal of Cross-Cultural Psychology, 32 (2), 186-201.

Phinney, J., \& Vedder, P. (2006). Family relationship values of adolescents and parents: intergenerational discrepancies and adaptation. In J. Berry, J. Phinney, D. Sam \& P. Vedder (Eds.), Immigrant youth in cultural transition: acculturation, identity and adaptation across national contexts ( $\mathrm{pp} 167$ - 184). Mahwah, NJ: Lawrence Erlbaum Ass.

Reijneveld, S., Harland, P., Brugman, E., Verhulst, F., \& Verloove-Vanhorick, S. (2005). Psychological problems among immigrant and non-immigrant children. European Child and Adolescent Psychiatry, 14 (3), 145-152.

Sameroff, A., Seifer, R., Bald win, A., \& Baldwin, C. (1993). Stability of intelligence from preschool to adolescence: the influence of social and family risk factors. Child Development, 64, 80-97.

Sellers, R., \& Shelton, J. (2003). The role of racial identity in perceived racial discrimination. Journal of Personality and Social Psychology, 84, 1079-1092.

Selten, J.P., Slaets, J., \& Kahn, R. (1997). Schizophrenia in Surinamese and Dutch Antillean immigrants to the Netherlands: evidence of an increased incidence. Psychological Medicine, 27, 807-811.

Selten, J.P., Veen, N., Feller, W., Blom, J.D., Schols, D., Camoenië, W., Oolders, J., Velden, M. van der, Hoek, H., Vladar Rivero, V., Graaf, Y. van der, \& Kahn, R. (2001). Incidence of psychatic disorders in immigrant groups to The Netherlands. British Journal of Psychiatry. 178, 367-372.

Selten, J.P., Zeyl, C., Dwarkasing, R., Lumsden, V., Kahn, R., \& Harten, P. van (2005). Firstcontact incidence of schizophrenia in Surinam. British Joumal of Psychiatry, 186, 74-75.

Shrake, E.K., \& Rhee, S. (2004). Ethnic identity as a predictor of problem behaviours among Korean American adolescents. Adolescence, 39, 601-622.

Stevens, G., Pels, T., Vollebergh, W., Bengi-Arslan, L., Verhulst, F., \& Crijnen, A. (2005). Emotionele problemen en gedragsproblemen bij Marokkaanse, Turkse en Nederlandse 4-18 jarigen in Nederland. Tijdschrift voor Psychiatrie, 47, 779-786.

Teebi, A.S., \& Farag, T.I. (Eds.)(1996) Genetic disorders among Arab populations. New York and Oxford: Oxford University Press.

Vedder, P. (1995). Antilliaanse kinderen; taal, opvoeding en onderwijs op de Antillen en in Nederland. Utrecht: Jan van Arkel.

Vedder, P., Horenczyk, G., \& Liebkind, K. (2006). Problems in ethno-cultural diverse educational settings and strategies to cope with these challenges. Educational Research Review, 1 (2), 157-168.

Vedder, P., \& Oortwijn, M. (in press). Adolescents' obligations toward their family: intergenerational discrepancies and adaptation in three cultural groups in the Netherlands. Vedder, P., \& Vijver, F. van de (2003). De acculturatie en adaptatie van migrantenjongeren in Nederland. Een vergelijkende studie. Migrantenstudies, 19 (4), 252-265.

Vijver, F.J.R. van de, \& Leung, K. (1997). Methods and data analysis for cross-cultural research. Newbury Park, CA: Sage.

Vollebergh, W., Have, M. ten, Dekovic, M., Oosterwegel, A., Pels, T., Veenstra, R., Winter, A. de, Ormel, H., \& Verhulst, F. (2005). Mental health in immigrant children in the Netherlands. Social Psychiatry and Psychiatric Epidemiology, 40, 489-496. 
Aanbevolen literatuur

Achenbach, T., \& Rescola, L. (2006). Multicultural understanding of child and adolescent psychopathology. New York: The Guilford Press. (Voor lezers met redelijke kennis van onderzoek en statistiek. Maakt duidelijk dat er bij her diagnosticeren van psychopathologie bij kinderen en volwassenen belangrijke validiteitproblemen bestaan. Veel aandacht gaat uit naar geringe overeenstemming tussen oordeelsvorming op basis van verschillende bronnen, bijv. gestandaardiseerde vragenlijsten en klinische interviews. Informatie over hoe in een diagnostische setting om te gaan met culturele diversiteit bevat het boek niet.)

Eldering, I. (2006). Cultuur en opvoeding. Rotterdam: Lemniscaat. (Veel informatie over cultuur en leefwereld van belangrijke migrantengroepen in Nederland, vooral toegespitst op kinderen, jongeren en hun opvoeders. Relevantie voor pedagogische situaties wordt verduidelijkt, terwijl de stap richting interventies en preventie door de lezer zelt gemakkelijk kan worden gezet.)

Korrmann, F. (2006). Transculturele psychiatrie. Assen: Van Gorcum. (Veel casusbeschrijvingen en een poging een model te beschrijven dat leidinggevend kan zijn voor werken met personen uit niet-westerse culturen. verlokt de lezer tot zelfverkenning en positiebepaling in een beroepsveld dat sterk wordt gekleurd door medisch, universalistisch denken dat in een multiculturele beroepspraktijk beperkt bruikbaar en soms ronduit inadequaat is.) 